\title{
Potential for Domestication of Panstrongylus geniculatus (Latreille, 1811) (Liemiptera, Reduviidae, Triatominae) in the Municipality of Muaná, Marajó Island, State of Pará, Brazil
}

\author{
Vera da Costa Valente \\ Instituto Evandro Chagas, Programa de Doenças de Chagas, Rodovia BR 316, km 7 s/no., 67030-070 \\ Ananindeua, PA
}

Key words: Panstrongylus geniculatus - Trypanosoma cruzi - Triatominae - Pará

\begin{abstract}
Panstrongylus genicutalus is a triatomine bug associated in the classical manner with animal burrows in humid forests, especially with armadillos that are the principal reservoirs of Z3 of Trypanosoma cruzi (Lent \& Wygodzinski 1979, Sherlock 1979, Miles et al. 1981). In spite of its occasional entry into houses where it is attracted by light, this triatomine has not established itself in habitations, an important factor in limiting the potential of this species as a vector of Chagas disease to man (Naiff et. al 1998). Colonization by this species of pigsties near to and contiguous with human dwellings in the Amazon River floodplain is here reported, for the northern Brazilian municipality of Muaná on Marajó Island in the Amazon River estuary, with concomitant invasion of human domiciles and attacks on residents therein (Valente et al. 1998).
\end{abstract}

During field work, 564 triatomines were collected in houses, outbuildings and palm trees at the localities Pau Grande, Capitariquara, Inamaru, Mocajatuba, Abacatal River, and Flexal. Five species were found: P. genicutatus, Rhodnius pictipes, $P$. lignarius, $R$. robustus, and Eratyrus mucronatus, with the first mentioned species being dominant $(89.4 \%)$. This species showed an index of $16.4 \%$ (27/167 specimens examined) in natural infection by trypanosome type cruzi.

Only Z1 of $T$. cruzi, previously associated with marsupials and $R$. pictipes, was isolated from triatomines and mammals in the vicinity. The natural infection by $P$. geniculatus by $\mathrm{Z} 1$ suggests a change in the behavior of this vector, most likely

Part of MSc Thesis presented to the Federal University of Pará

Fax: +55-91-266.2016. E-mail: avalente.bel@zaz.com.br Received 9 June 1999

Accepted 9 August 1999 due to alterations in its environment (Valente et. al. 1998). In all, 26 specimens of this species of triatomine were collected in human dwellings, 5 $(18.5 \%)$ naturally infected with the trypanosome.

Of 122 houses examined, 28 (23\%) were infested and yielded a total of 40 adult triatomines.

Some 114 domestic mammals (105 pigs, 5 dogs, and 4 cats) and 7 wild mammals (4 Didelphis marsupialis, 2 Philander opossum, and 1 Proechymis guyanensis) were examined, and natural trypanosome infections were found in 4 pigs (Sus scrofa) (2.8\%), 4 D. marsupialis and 1 P. opossum. The natural infection of domestic pigs with $\mathrm{Z} 1$ in sties colonized by $P$. geniculalus is a relevant finding, as well as being the first report of an association between triatomines and domestic animals in the Amazon Basin (Valente 1998).

No human trypanosome infection was found in the studied communities, where 582 residents of a total population of 678 people were tested, and all were serologically negative. The possibility of infections arising from the proximity to swine is present, especially given the local, exuberant habit of some people of smearing their unprotected hands with pig blood during butchering of the animals.

The registered adaptability of $P$. geniculalus to swine and pigsties in the vicinity of human dwellings, in the floodplain, and their attack on people in houses, indicate that this could be a potential pathway to the domestication of this triatomine in the Amazon River delta (Valente 1998).

From this study the following conclusions can be made: (1) colonization by $P$. gerncuialus of pigsties near human habitations has been demonstrated, and specimens of this species naturally infected with Z1 of $T$. cruzi were collected in the adjoining human dwellings where there was also some evidence that these triatomines may have bitten people, in spite of these findings, no human infection of $T$. cruzi was found in the study community; (2) five species of triatomines are found in the study area: $P$. geniculatus, $R$. pictipes, $P$. 
lignarius, $R$. robustus, and E. mucronatus, with the first-mentioned species being predominant $(89 \%$ of the collected specimens); (3) all samples of $T$. cruzi isolated from either triatomines or wild mammals in the study area belong to $\mathrm{Zl}$; (4) naturally infected domestic pigs (S. scrofa) were found to harbor $\mathrm{Z} 1$ of $T$. cruzi, in pigsties colonized by $P$. genicutatus; (5) the possibility exists that people in the region could develop cases of Chagas disease from the ingestion or handling of pig meat infected with $T$. cruzi, due to a lack of an inspection service for pork that is sold in the area; (6) the main factors that have caused these wild vectors to invade human dwellings seem to be the devastation of the primary forests, over hunting, and burning of forests, all of which destroyed the triatomines' natural habitat and caused them to seek alternative shelter and hosts; (7) the adaptability of $P$. geniculatus to the enclosures of domestic pigs near to human dwellings on the river flood plain and the attack of these triatomines on people within these houses indicate that this scenario could well be a route to the domestication of this species in the Amazon River delta; (8) the adoption of vector control measures in the region is recommended, in order to stop the process of domestication of triatomines in this area.

\section{REFERENCES}

Lent H, Wygodzinski P 1979. Revision of the Triatominae (Hemiptera, Rediviidae) and their significance as vectors of Chagas disease. Bull Am Mus Nat Hist 163: 1-529.

Miles MA, Souza AA, Póvoa MM 1981. Chagas disease in the Amazon Basin. III. Ecotopes of ten triatomine species (Hemiptera, Reduviidae) from the vicinity of Belém, Pará State, Brazil. J Med Entomol 18: 266-278.

Naiff MF, Naiff RD, Barret TV 1998. Vetores selváticos de doença de Chagas na área urbana de Manaus (AM): atividade de vôo nas estações secas e chuvosas. Rev Soc Bras Med Trop 31: 103-105.

Sherlock I 1979. Epidemiologia, p.89-151. In Trypanosoma cruzi e Doença de Chagas. Guanabara Koogan, Rio de Janeiro.

Valente VC, Valente SAS, Noireau F, Carrasco HJ, Miles MA 1998. Chagas disease in the amazon Basin: association of Panstrongylus geniculatus (Hemiptera: Reduviidae) with domestic pigs. J Med Entomol 35: 99-103.

Valente VC 1998. Potencial de Domiciliação de Panstrongylus geniculatus (Latreille, 1811) (Hemiptera, Reduviidae, Triatominae) no Município de Muaná, Ilha de Marajó, Nordeste do Estado do Pará, Brasil, MSc Thesis, Curso de Pós-Graduação em Ciências Biológicas, Universidade Federal do Pará, Belém. 